whether the patient is mentally competent, whether the patient has sufficient knowledge of the medical condition and possible treatment options if there is a known illness, and whether the patient is being coerced into making decisions by other people.

\section{Format of statements}

Oral statements are likely to be legally valid if supported by appropriate evidence but there are clear advantages to recording general views and specific refusals in writing. Advance statements are an aid to, rather than a substitute for, open dialogue between patients and health professionals. There are no specific legal requirements concerning the format of advance statements but it is recommended as a minimum, that the following information is included: full name, address, name and address of general practitioner, whether advice was sought from health professionals, a clear statement of wishes or the name, address and telephone number of a person to be consulted, signature and the date the document was written and reviewed. It is recommended that the statement is reviewed on a regular basis and at least every five years. The only minimum requirements for legal validity are that the patient is competent at the time of making the statement, is aware of the implications of the decision and that the circumstances match those in the statement.

Advance Statements About Medical Treatment is avallable from BMJ Publishing Group, PO Box 295, London WC1H 9TE (tel: 01713836185 ) and costs $\$ 4.95$ for BMA members and $\$ 5.95$ for non-members.

Advance Statements About Future Medical Treatment. A

Guide for Patients can be purchased from the Patient's Assoctation, 8 Guilford Street, London WCIN IDT (tel: 0171 242 346).

\title{
Continuing Professional Development Validation
}

From the 1 January 1996, the application form for the validation of all CPD events will be available on request from the College. Completed forms relating to national or international CPD events should be returned to the College to be processed. Completed forms relating to regional or local events should be returned to the CPD Deputy Regional Adviser (details available on the application form).
For more information please contact Mrs Jean Wales, CPD Officer or Ms Pauline Taggart, CPD Administrator at the following address: The Royal College of Psychiatrists, 17 Belgrave Square, London SW1X 8PG (Tel: 0171-235 2351 extension 270 or 112).

\section{Log Books or Personal Training Files - A College Working Party}

A working party has been established at the request of the Education Committee and the Tutor's Sub-Committee, with the support of the Dean. Its remit is to supervise an 18-month evaluation of a pilot document (the Log Book or Personal Training Fule) which can be used by trainees at the current senior house officer (SHO) and registrar grades as a means of facilitating the recording and planning of their training in psychiatry.

The pilot document, available in the form of a slim, loose-leaf A4 folder, represents a compromise between portability and ease of use. It is intended to be held by the trainee, and to remain their personal property. Space is allowed to record experience in individual posts, to set educational 


\section{THE COLLEGE}

objectives with trainers, to record specific experience and acquisition of skills, and document courses attended, research and audit experience, as well as regular feedback on the trainee's progress. This will assist College tutors in reviewing training and provide a focus for supervision discussions between trainee and trainer. It is intended that trainees use it themselves to think about and plan their own training.

The pilot document is being evaluated in NE Thames, Keele, Leeds|Wakefield, Liverpool and Dublin. Regular feedback is to be obtained from trainees and trainers. A number of other schemes have expressed interest in the Log Book and are likely to be implementing it and providing informal feedback. Any scheme interested in doing so may freely reproduce the document if they wish for local use but if so notification of that intention is expected, and contribution of informal feedback appreciated.

At the end of the 18-month evaluation period, a report will be submitted to the sponsoring committee which will continue to establish College policy on the use of $\log$ books and decide whether the College approves a specified document for national implementation. Copies of the pilot document are avallable from Catherine Lightfoot, Postgraduate Education Administrator at the College. Members of the Working Party below may be approached for further discussion.

Dr Annie Hall (CTC Representative), 8 Oval Road, East Croydon CRO 6BG; Dr Sharma, Fazakerley Hospital, Longmoor Lane, Liverpool L9 7ALi Dr Thorley, City General Hospital Psychiatric Unit, Newcastle Road, Stoke-on-Trent ST4 6QG; Dr Bird, Royal Free Hampstead NHS Trust, 61 Belsize Avenue, Hampstead NW3 4BN; Prof. Casey, Dept. of Psychiatry, Mater Hospital, 62/63 Eccles Street, Dublin 7; Dr Bolton, Dept. of Mental Health Sclences, St George's Hospital Medical School, Jenner Wing, Cranmer Terrace, London SW17 ORE, Dr Newby, High Royds Hospital, Menston, Ilkley LS29 6AQ

\section{List of assessors}

We would like to thank the following who have acted as specialist assessors of papers during the past year.
D. Abrahamson
P. Campbell
G. Adshead
J. Coid
G. Andrews
A. Cooklin
M. Ekdawi
L. Appleby
J. E. Cooper
T. Arie
R. Cope
C. Cordess
J. Evans
M. Aveline
D. Cottrell
S. Bailey
J. Cox
I. E. Babiker
J. L. Crammer
T. R. E. Barnes
F. Creed
J. Beecham
A. H. Crisp
M. Berelowitz
J. Cooper
T. Berney
A. David
D. Black
K. Davidson
A. Farmer
G. Fenton
I. N. Ferrier
N. Fineberg
C. B. Flannigan
M. W. Forth
R. France
K. Fraser
W. Frazer
C. Freeman
H. Freeman
I. Blackburn
A. Davies
K. Fulford
R. Bloor
S. Davies
I. Fyfe
K. Davison
E. M. Gadd
C. Bools
K. Day
N. Bouras
C. Dean
R. Gater
F. Denman
H. Ghodse
I. Brockington
E. Gilvarry
B. Brockman
K. Dwivedi
J. M. Eagles
N. Gittleson
T. Brugha
P. Graham
A. Burke
N. Eastman
S. Grant
S. Gravestock
A. Burns
D. Eccleston
A. Grounds
T. Burns
G. Edwards
P. Groves
G. Calvert
D. Grubin 